\title{
Green Office Building Environmental Perception and Job Satisfaction
}

\author{
Sariya Saengsawang* and Supeecha Panichpathom
}

Thammasat Business School, Thammasat University, 2 Prachan Road, Pranakorn, Bangkok - 10200 Thailand

\begin{abstract}
The paper investigated the factors affecting job satisfaction in office buildings with LEED quality certification. The findings were useful information to help tenants make decision more easily when they perceive benefits from renting certified office buildings in Thailand. Also it supported investors to improved and designed to hold future sustainable innovations. This research used questionnaires as the instrument. Pre-test was completed by 10 respondents in order to evaluate the lucidity of questions, and to revise incomprehensible or unclear ones. Cronbach's alpha was applied to examine the validity of each construct. Exploratory factor analysis was brought to group relating variables all together in the same components for fewer variables. All questions had been revised again to get the ones that cover the objectives of the research and all targeted factors before real data was collected from at least 200 samples. The valid sample size was 286. Respondents are employees working at green office buildings in Bangkok. We gathered data by directly distributing structured questionnaires at Park Venture, AIA Capital Center and Sathorn Square and via Google Docs in February 2016. After performing an exploratory factor analysis and multiple regression analysis, we found the significant direct relationship between three independent constructs, namely perceived indoor air, thermal, acoustic and visual, and job satisfaction. The study showed the importance of indoor environment, especially on perceived indoor air quality. This paper shed the light to the office building renters and/or investors in Thailand that they should select or renovate office building toward green designs. Green office buildings attract office rates, provide better human capital management, lead to better competitive advantages in doing business and attract management of corporations who are concerned with employees' job satisfaction and environmental factors that contribute to employees' satisfaction.
\end{abstract}

Keywords: Job Satisfaction, Perceived Indoor Air Quality, Perceived Thermal, Perceived Acoustic, Green Office Building, Environmental Factors

\section{Introduction}

Nowadays, giving precendence to environment, energy consumption, and impacts of energy consumption on environment tends to become a major trend more than before. That is because it can enhance competitive efficiency and communicate good images to public. Many companies, therefore, focus on the significance of CSR (Corporate Social Responsibility); and thus it affects changes in real estate business as well, that is, offices for rent, or green buildings in particular. These buidlings are different from other general ones in the sense that they are basically designed for effective energy consumption, adjusting balance to suit users, and eco-friendly look. *Email: s.sariaire@gmail.com
supeecha@tbs.tu.ac.th 
Thus, most tenants realize the importance of green buildings and want to stay in them, with their interest in gaining benefits from the use of being "green". Indoor environment is mainly focused as the vital factor to be considered for finding new rental spaces/offices. Green buildings with quality improvement are required, i.e., air quality, illuminance, temperatures, humidity, and noises. Tenants are even also willing to pay extra costs for office rental inside green buildings (บุญเกียรติ วิสิทธิกาศ, B.E. 2552).

If viewing with regard to investors, green buildings do not only create higher rental incomes than other regular office buildings, and possess the lower tendency of unoccupied space rates than those without green quality certification (Fuerst, McAllister, Wetering, \& Wyatt, 2011), but also generate long-lasting and higher returns throughout the project. In other words, to invest more from values of general projects in order to initiate certified green office buildings make higher returns all through the project than those without the mentioned certification. It is the direct result that can be seen obviously from resource and water saving; and waste reduction (Kats, Alevantis, Berman, Mills, \& Perlman, 2003). This also includes benefits for building users such as, health matters and work performance (Wyon, 2004).

Therefore, to invest in certified green office buildings is an advantage for competitions in current markets in which the development of real estates is conducted by the use of technology as well as design that take environmenal effects and users into consideration, more.

Besides, the selection of space rental in green buildings is frequently related to health and work performance of users. As it is widely known, that a company's investment mostly comprise of investment with staff who must work indoor 5 days per week and 8 hours per day, what should be inevitably regarded in this investment as returns from human resource investment, that is, full exploitation of efficiency for highest returns in the buildings designed for sustainability and good health of users, which can lift up work performance. To work in pleasant environment, therefore, can positively assist building users regarding facility and reduced impacts that might happen to health, e.g. discomfort, losing concentration, or pollution from buildings. So, to rent certified offices help influencing higher work performance under fine environment, e.g., temperatures, illuminace, natural light, decoration with proper color tones, noise control, work space design, and indoor air quality.

Green buildings embrace qualifications influencing satisfaction towards environments, temperatures, sceneries, attractiveness, noises from air coolers, working images, sleeping, emotional state, physical reactions, and low particles in the air. These qualifications are superior to general buildings (Newsham et al., 2012). Staying in buildings without green quality certification possibly links to sickness building syndrome, which, in terms of business outcomes, leads to more work absence or higher expenditures concerning staff's health, including lower work performance (Sentman, 2009).

The better improvement of indoor environment affects report of staff's sickness, sickness building syndrome, allergies, asthma, and results of work. This means the reduction of expenditures on account of staff's poor health and getting back to higher work performance (Fisk, 2000). Or even changing some indoor qualifications, e.g., proper ventilation, confirms that benefits from work are higher than lost expenditures due to sickness building syndrome or work absence due to sick leave. It also acts on work performance (Park \& Yoon, 2011) and report of dissatisfaction towards indoor air quality when more air circulation is required. This can be interpreted that if staff perceive the circulation, it will raise satisfaction (Haghighata \& Donnini, 1999). The increase of air circulation can drop down sick leave (Milton, Glencross, \& Walters, 2000). At the same time, if staff work under improper temperatures, e.g., too high ones, it can touch on work competency, too (Seppänen \& Lei, 2006). Or even designing workplace to get natural light with the visual of external sceneries can also make staff feel good towards their jobs (Linderberger and Zagicek, 2008) and feel that they are healthy (Heschong, 2003). This reveals that environment of buildings can have a bearing on work performance.

In this study, the researcher paid particular attention to job satisfaction in the particular certified green 
building in Thailand. Despite higher rental cost than other general buildings, most companies can make returns from work of their staff. We all perceive that hiring costs are usually higher than building expenditures. This allow higher work performance to speed up payback (Clements-Croome \& Luck, 2003). Likewise, to motivate returns by motivating satisfaction so as to increase work performance can be done through the selection of buildings that can help keeping staff in good health. Based on the records of the Real Estate Information Center (REIC), which is an official body disseminating information pertaining to real estate business, in Thailand, the prominent office buildings that grants the Leadership in Engineering and Environment Design or LEED certification are park venture, SCG, AIA Capital, Sathorn Square, and Energy complex. LEED is a green building standard evaluation, an eco-friendly evaluation system of buildings or constructions that has been accepted and applied worldwide most. The standard was developed by U.S. Green Building Council (USGBC), with the objectives to enhance building resource usage efficiency and to help reduce negative impacts on environments and sanitation of building users. The whole life cycles of 5 buildings are pondered, i.e., park venture, SCG, AIA Capital, Sathorn Square, and Energy complex. There are over 60 buildings that have been under the process of approval request for the U.S. standard and Thai Green Building Institute (TREES). This indicates that there are still a few green buildings in Thailand of which structures are improved and designed to hold future sustainable innovations. This might be the consequence of lack of confidence among investors in real estate businesses towards spending money on extra investment in green buildings as they are not sure whether tenants will choose to rent the buildings or not, since those tenants do not see tangible benefits from larger payment for green building rental.

Till recently, there have been merely a few specific studies about certified green buildings. Also, as LEED quality certification is an international standard accepted worldwide with eco-friendly qualifications and helps job satisfaction, it is an interesting to analyze independent factors relating to job satisfaction in an office building certified with LEED quality certification. The findings will be useful information to help tenants make decision more easily when they perceive benefits from renting certififed office buildings.

\section{Literature Review}

In literature review, the researcher reviewed and concluded essential issues from relevant documents as follows:

\subsection{Job Satisfaction}

Job satisfaction is building occupants' positive feeling towards their jobs and workplace. So, it can be defined as satisfaction arisen from needs in workplace (Togia, Koustelios, \& Tsigilis, 2004). It is for measure satisfaction towards jobs or other dimensions of work (Christian, Garza, \& Slaughter, 2011; Ritz, 2009). Or it means the joy of work success or simply achieving work goals (Behson, Eddy, \& Lorenzet, 2000). It is the feeling that is more than liking or disliking their jobs (Spector, 1997). As a whole, it is staff's feeling towards their job that refers to overall images of jobs, co-workers, or even incomes and conditions ( $\mathrm{Lu}$ et al, 2005). It might also be a result from relations among co-workers, management systems, or office mates (Onsman, 1999). Job satisfaction might emerge from age, gender, educational level, work environment, co-workers, income, and work hours (Bodur, 2002). High job satisfaction has impacts on businesses both in terms of higher profits and higher consumer satisfaction. It brings about less job rotation in companies as well (Branham, 2005), because very satisfied staff will not want to leave their workplace (Hanson \& Miller, 2002). Furthermore, it was also found that job satisfaction is another factor of organizational success (Sink, 1985).

\subsection{The Relations Between Perceived Workplace Environment and Job Satisfaction}

Workplace environment means to prepare places for work in order to produce the most effective work outcomes. Workplace design must emphasize on ergonomics and the sequence of work implementation. 
Work outcomes or results are indicators of how to extend the effective use of work spaces (Hameed \& Amjad, 2009). Furthermore, when work starts to become a routine, be able to predict, and must meet standards; including work of which responsibilites need to be divided clearly or follow procedures for desion making, it is even more necessary to lean on workplace design according to processes and necessity for work communications (John et al., 2009). Hence, the suitable arrangement of workplace, air systems, illuminance, temperatures, cleanness, and all-around areas is indispensable for workplace.

Previous studies showed qualifications indicating workplace environment and its influences on job satisfaction in rental office buildings. When considering those factors aforesaid, including researches that presented workplace environment associated with qualifications of office buildings with LEED quality certification as shown in Table 1, this study investigated the 4 main factors, i.e., indoor air quality, temperatures, visual, and noises.

Table 1. Qualifications of LEED certified office building

\begin{tabular}{|l|l|}
\hline Qualifications & Quality certifications \\
\hline Sustainable & $\begin{array}{l}\text { Decrease construction pollutions, such as the controls of } \\
\text { soil erosion, waterway sedimentation, and airborne dust. } \\
\text { Moreover, engender the good health of people occupied in } \\
\text { the building, reserve the natural areas and recover damaged } \\
\text { areas. }\end{array}$ \\
\hline $\begin{array}{l}\text { Water } \\
\text { Efficiency }\end{array}$ & $\begin{array}{l}\text { All projects aim to conserve any sources of water, such as } \\
\text { rainfall or recycled water. }\end{array}$ \\
\hline $\begin{array}{l}\text { Energy \& } \\
\text { Atmosphere }\end{array}$ & $\begin{array}{l}\text { All projects are designed to reduce the negative impacts } \\
\text { toward environment, including the energy and indoor } \\
\text { environment. }\end{array}$ \\
\hline $\begin{array}{l}\text { Material \& } \\
\text { Resources }\end{array}$ & $\begin{array}{l}\text { Decrease the waste generated by building occupants, } \\
\text { dispose waste and demolish waste in landfills, and also urge } \\
\text { the adaptive reuse of products and materials. }\end{array}$ \\
\hline
\end{tabular}

\begin{tabular}{|l|l|}
\hline Qualifications & Quality certifications \\
\hline Indoor & The quality of indoor environment that provide building \\
Environmental & $\begin{array}{l}\text { occupants the comfort and well-being, promotes their } \\
\text { Quality } \\
\text { comfort, well-being, and productivity, reduces the damages } \\
\text { caused by the chemical contaminants, generates better } \\
\text { quality indoor air in the buildings. }\end{array}$ \\
\hline Innovation in & $\begin{array}{l}\text { Projects are designed to get exceptional or innovative } \\
\text { performance. }\end{array}$ \\
\hline Design & $\begin{array}{l}\text { Set the incentive for the achievement of credits that help } \\
\text { solving the issues pertaining to specific environmental, social } \\
\text { Priority Credit } \\
\end{array}$ \\
\hline
\end{tabular}

\subsection{Perceived Indoor Air Quality}

For common people, over $90 \%$ of their time is spent indoor. Thus, indoor air quality certainly impinge users' feeling of comfort and health (Samaranayake \& De Silva, 2010). For this reason, office buildings for rent should be in environment that promotes better work performance of indoor staff. Quality of indoor environment can produce both tangible and psychological effects on staff. In addition, investmentfor indoor environmental improvement can bring outcomes in a form of greater work performance as well (Bruhns, 1996; Sullivan, Baird, \& Donn, 2013; U.S. Green Building Council, 2015). There were reports that most staff believe their job satisfaction increases when LEED quality is utilized indoor. This satisfaction takes place from gaining physical benefits of being green budilings (Kato, Too, \& Rask, 2009). Apart from these, indoor environment also acts upon long-term commitment with companies (Heath et al., 2006). So, it can be said that indoor environmental quality is significant to job satisfaction (Kato et al., 2009; Kirsten, 2007).

\section{H1: Perceived indoor air quality has positive relations with job satisfaction.}

Perceived Thermal The feeling of thermal comfort basically occurs to individuals with different thermal preference. In general buildings, most air coolers as well as heaters offer certain stable levels of temperatures (The Human Resources Social Network, 2005). Working under fine temperatures can lessen staff's tension and lead to gratifying work outcomes (Ajala, 2012).

\section{H2: Perceived Thermal have positive relations with job satisfaction.}

\section{Perceived Visual}

Lighting quality has impacts on work performace. Similarly, natural light plays an important role to work performance (Loftness, Hartkopf, Gurtekin, Hansen, \& Hitchcock, 2003). It dimishes ocular fatique, indoor accidents, and work errors due to using both eye sights and hands simultaneously. Less errors or mistakes definitely create better effects on companies (Ajala, 
2012). Indoor lighting or illuminance is another crucial factor for work accomplishment. Working under inadequete lights causes ocular fatique, headache, and frustration (Hameed \& Amjad, 2009). Th accessibility of natural light directly involves satisfaction towards job and quality of life. It also draws opposite outcomes pertaining to resignation (Leather, Pyrgas, Beale, \& Lawrence, 1998; Newsham et al., 2009).

\section{H3: Perceived visual has positive relations with job satisfaction.}

\section{Perceived Acoustics}

Sounds are a way of communication with exact purposes while noises allude to unwanted sounds which originate physical and psychological effects. There upon, noises can be regular sounds in workplace such as talks or telephone rings (Sundstrom, Town, Rice, Osborn, \& Brill, 1994). Even so, they can cut down concentration on work (Banbury \& Berry, 2005) although they are always heard all the time like sounds from ventilation systems or repeated ones like nonstop pressing sounds or hits. These noises can decrease work accuracy. Those inevitable for work, e.g., talks or telephone rings usually heard in open office spaces can also cause tension to staff. Furthermore, more annoyance against noises can result in higher risk of high blood pressure, too (Lercher, Hortnagl, \& Kofler, 1993). Following the experiment of Evans \& Johnson,
2000, it was found that low intensity noises did not have effects on basic work, but a tension hormone had been discovered after about 3 hours even though staff wrote down in the questionnaires that those noises neither had any impacts on their mental states nor work motivation at all.

Other than those, perceived noises in workplace also entail the loss of concentration. Consequently, work performance drops, huge mistakes on work occurs, and work tension rises. The reduction of noises during work can relieve tension, especially for staff who have to work on information input. It can also accrue work accuracy, work achievement, and work effectiveness (Ajala, 2012). Independent variable as perceived thermal, indoor air quality, visual, and acoustics, and job satisfaction as dependent variable can be shown in conceptual frame work of this study in figure 1 .

\section{H4: Perceived Acoustics have positive relations with job satisfaction.}

\section{Research Methodology}

Researcher using Quantitative methods to study the impaction of perceived qualifications of office buildings with LEED quality certification to employee Job Satisfaction Questionnaires were directly distributed at LEED certificated office building in Bangkok and via Google Doc.

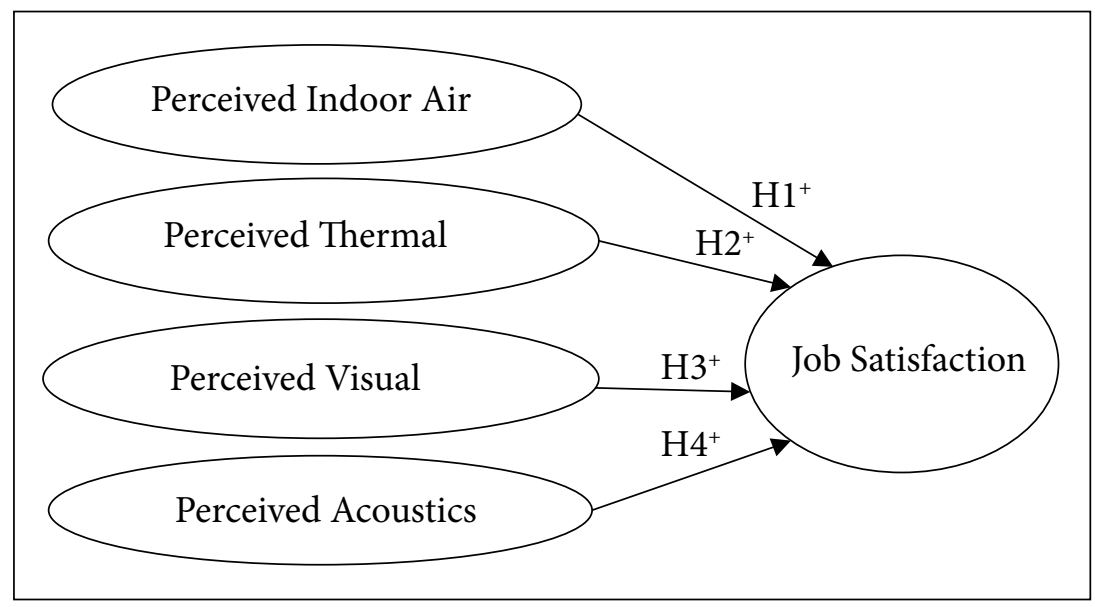

Figure 1. Conceptual framework of this study. 


\subsection{Population and Sampling}

1. Population: Employee in green office buildings

2. Sampling: Employee in LEED certificated office building in Bangkok such as Park Venture, Sathorn Square, AIA Sathorn, AIA Capital and SCG 100 years building

\subsection{Data Collection}

This research collected data from the office buildings with LEED quality certification in Bangkok, i.e., Park Venture, Sathorn Square, AIA Sathorn, and AIA Capital. Structured questionnaires were used to gather the data through convenient sampling. All of them were distributed directly to the samples who worked in the subjected offices. Meanwhile, online questionnaires were sent through Google Doc as well, during 7-20 February 2016.

The research used questionnaires as the instrument. Pre-test was completed by 10 respondents in order to evaluate the lucidity of questions, and to revise incomprehensible or unclear ones. Cronbach's alpha was applied to examine the validity of each construct. Exploratory factor analysis was brought to group relating variables all together in the same components for fewer variables. All questions had been revised again to get the ones that cover the objectives of the research and all targeted factors before real data was collected from at least 200 samples.

\section{Results and Discussions}

Table 2. Results derived from multiple regression analyses toward Job Satisfaction

\begin{tabular}{|l|l|l|l|l|l|}
\hline \multicolumn{7}{|l|}{ Model } & R & R Square & Adjusted R Square & $\begin{array}{l}\text { Std. Error of the } \\
\text { Estimate }\end{array}$ \\
\hline dimension0 & 1 & $.555^{\mathrm{a}}$ & .308 & .298 & .83626804 \\
\hline
\end{tabular}

a. Predictors: factor scores of perceived indoor air quality; of perceived thermal; of perceived visual and of perceived acoustics.

The results of this study (Table 2) demonstrated that the factors of perceived temperatures, indoor air quality, visual, and noises could be manipulated to analyze job satisfaction. It was revealed that perceived indoor air quality affected job satisfaction most, followed by perceived visual, temperatures, and noises, respectively. In this case, ANOVA Test was exploited as shown in Table 2. F $=31.381$ and Sig $=0.0020 .0000 .000$ and 0.006 , in order. The values were below the statistical significance at 0.05 . Those variables composed of the independent variables that could explain changes of the dependent ones or job satisfaction as 0.298 or

ANOVA $^{\mathrm{c}, \mathrm{d}}$

\begin{tabular}{|l|l|l|l|l|l|}
\hline Model & Sum of Squares & df & Mean Square & F & Sig \\
\hline 1 Regression & 87.785 & 4 & 21.946 & 31.381 & $.000^{\mathrm{a}}$ \\
\hline Residual & 197.215 & 282 & .699 & & \\
\hline Total & $285.000^{\mathrm{b}}$ & 286 & & & \\
\hline
\end{tabular}

a. Predictors: Predictors: factor scores of perceived indoor air quality; of perceived thermal; of perceived visual and of perceived acoustics.

b. This total sum of squares is not corrected for the constant because the constant is zero for regression through the origin.

c. Dependent Variable: factor score of Job Satisfaction.

d. Linear Regression through the Origin.

Coefficients $\mathrm{a}^{\mathrm{a}, \mathrm{b}}$

\begin{tabular}{|c|c|c|c|c|c|}
\hline Model & Unsta & Coefficients & Standardized Coefficients & & \\
\hline & $B$ & Std. Error & Beta & $t$ & Sig \\
\hline 1 REGR factor score_Thermal & .159 & .050 & .159 & 3.201 & .002 \\
\hline REGR factor score_Indoor Air Quality & .433 & .050 & .433 & 8.739 & .000 \\
\hline REGR factor score Visual & .277 & .050 & .277 & 5.598 & .000 \\
\hline REGR factor score_Acoustic & .136 & .050 & .136 & 2.753 & .006 \\
\hline
\end{tabular}

a. Dependent Variable: factor score of Job Satisfaction

b. Linear Regression through the Origin 
29.8\%. And from Table 2, it can be concluded that the independent variables that influenced job satisfaction with statistical significance could be displayed in a form of equations:

$$
\begin{gathered}
\text { Job Satisfaction }=0.159(\text { Thermal }) * *+0.433 \text { (Indoor } \\
\text { Air Quality) } \\
+0.138(\text { Visual }) * *+0.277 \text { (Acoustic) })^{* *} \\
* * \text { p-value }<0.01 \\
* \text {-value }<0.05
\end{gathered}
$$

The authors performed Stepwise linear regression analysis using Factor Scores of each Independent Variables to test our hypothesis. The results indicated all hypotheses were supported (Table 3 ).

Table 3. Results from Multiple Regression Analysis: Stepwise

\begin{tabular}{|l|l|l|l|l|}
$\begin{array}{r}\text { Independent } \\
\text { Variable } \\
\begin{array}{l}\text { Dependent } \\
\text { Variable }\end{array}\end{array}$ & $\begin{array}{l}\text { Perceived } \\
\text { Thermal }\end{array}$ & $\begin{array}{l}\text { Perceived Indoor } \\
\text { Air Quality }\end{array}$ & $\begin{array}{l}\text { Perceived } \\
\text { Visual }\end{array}$ & $\begin{array}{l}\text { Perceived } \\
\text { Acoustic }\end{array}$ \\
\hline Job Satisfaction & $0.159^{\star \star}$ & $0.433^{\star \star}$ & $0.277^{\star \star}$ & $0.136^{\star \star}$ \\
\hline $\mathrm{R}^{2}$ & 0.308 & & \\
\hline Adjusted $\mathrm{R}^{2}$ & 0.298 & & \\
\hline $\mathrm{F}$ & 31.381 & & \\
\hline Sig.F & 0.000 & & \\
\hline
\end{tabular}

Remarks: Regression Coefficients: Standardized Coefficients

- ** p-value $<0.01$

- * p-value $<0.05$

The results indicated that perceived therma, indoor air quality, visual, and acoustics impacted job satisfaction. Hence, this research confirmed Hypothesis 1, 2, 3, and 4. All of them proved that the subjected indoor environmental factors positively related to job satisfaction. The results conformed with the former study of Qasim, Cheema, \& Syed, 2012; Waqas et al., 2014, who investigated the factors influencing job satisfaction. However, in this research, the environmental factors described changes towards the relations with job satisfaction as $29.8 \%$. That is because job satisfaction can actually comprises of other several factors apart from indoor environment, for example, organizational cultures, work contents, welfare, rewards, acceptance, etc. These are all factors that have effects on job satisfaction as well (Hong, Hamid, \& Salleh, 2013; Qasim et al., 2012; Sypniewska, 2013; Tutuncu \& Kozak, 2007; Waqas et al., 2014).

\section{Conclusions and Discussions}

This research was the analysis of the relations of perceived indoor environmental quality towads job satisfaction in the green buildings. The study pointed that to place an importance to indoor environment should be responded by tenants, especially on perceived indoor air quality. The variables that should be paid special attention to included no frustration with indoor air, no unpleasant odours, choosing nontoxic decorations, good ventilation or air circulation, and fresh indoor air, consecutively. Nonstheless, the variables used to measure perceived visual were not clear, so the component seperation of variables in each involved factor arised and they could not be joined with other components. This did not match other existing studies. It, therefore, can be inferred that the designed questions were not quite good representative questions for indicating perceived visual towards job satisfaction. Or there might be some defects about the lucidity of the questionnaires, which made the respondents confused. Above all, perceived temperatures presented the variables that should be kept an eye on, i.e., stable temperatures, coldness as well as heat that encouraged work, and humidity as a factor that could evidently indicate perceived temperatures, subsequently. Indoor and outdoor noises, and sounds from air-conditioners were also the variables that explicitly clarified the meanings of perceived noises, in turn.

\section{Bibliography}

Ajala, E. M. (2012). The Influence of Workplace Environment on Workers' Welfare, Performance and Productivity. The African Symposium: An online Journal of the African Educational Research Network, 12(1), 9. PMCid:PMC3693651

Banbury, S. P., \& Berry, D. C. (2005). Office Noise and EmployeeConcentration:IdentifyingCausesOfDisruption And Potential Improvements. Ergonomics, 48(1), 13. https://doi.org/10.1080/00140130412331311390

Behson, S. J., Eddy, E. R., \& Lorenzet, S. J. (2000). The Importance of the Critical Psychological States in the Job 
Characteristics Model: A Meta-Analytic and Structural Equations Modeling Examination. Current Research in Social Psychology, 5.

Bodur, S. (2002). Job satisfaction Of Health Care Staff Employed At Health Centres in Turkey. Occuputional Medicine, 52(6), 3. https://doi.org/10.1093/occ$\mathrm{med} / 52.6 .353$

Branham, L. (2005). The 7 Hidden Reasons Employees Leave. Business Book Review, 22(3).

Bruhns, H. (1996). CBPR Checklist. Building Evaluation Techniques.

Christian, M., Garza, A., \& Slaughter, J. (2011). Work Engagement: A Quantitative Review and Test of its Relations with Task and Contextual Performance. Personnel Psychology 64, 48. https://doi.org/10.1111/ j.1744-6570.2010.01203.x

Clements-Croome, D. J., \& Luck, R. (2003). Environmental Quality and the Productive Workplace. CentAUR, 15.

Evans, G. W., \& Johnson, D. (2000). Stress and Open-office Noise. Journal of Applied Psychology, 85(5). https:// doi.org/10.1037/0021-9010.85.5.779

Fisk, W. J. (2000). Health and Productivity Gains from Better Indoor Environments and their Relationship with Building Energy Efficiency. Annual Review of Energy and the Environment, 25, 32. https://doi.org/10.1146/ annurev.energy.25.1.537

Fuerst, F., McAllister, P., Wetering, J. V. D., \& Wyatt, P. (2011). Measuring the Financial Performance of Green Buildings in the UK Commercial Property Market: Addressing the Data Issues. Journal of Financial Management of Property and Construction, 16(2), 24. https://doi.org/10.1108/13664381111153132

Haghighata, F., \& Donnini, G. (1999). Impact of psycho-social Factors on Perception of the Indoor Air Environment Studies in 12 Office Buildings. Building and Environment, 34, 25. https://doi.org/10.1016/ S0360-1323(98)00034-1

Hameed, A., \& Amjad, S. (2009). Impact of Office Design on Employees' Productivity: A Case Study of Banking Organizations of Abbottabad, Pakistan. Journal of Public Affairs, Administration and Management, 3(1), 13.

Hanson, M., \& Miller, A. F. (2002). The Productive use of Strengths: A Shared Responsibility. Industrial and Commercial Training, 34(3), 7. https://doi. org/10.1108/00197850210424935

Heath, G. W., Brownson, R. C., Kruger, J., Miles, R., Powell, K. E., \& Ramsey, L. T. (2006). The Effectiveness of Urban Design and Land Use and Transport Policies and Practices to Increase Physical Activity: A Systematic review. Journal of Physical Activity and Health, 3(1), 22. https://doi.org/10.1123/jpah.3.s1.s55

Heschong, L. (2003). Windows and Offices: A Study Of Office Worker Performance and the Indoor Environment. California: California Energy Commission.

Hong, L. C., Hamid, N. I. N. A., \& Salleh, N. M. (2013). A Study on the Factors Affecting Job Satisfaction Amongst Employees of a Factory in Seremban, Malaysia. Business Management Dynamics, 3(1).

Kato, H., Too, L., \& Rask, A. (2009). Occupier Perceptions of Green Workplace Environment: The Australian Experience. Journal of Corporate Real Estate, 11(3). https://doi.org/10.1108/14630010910985931

Kats, G., Alevantis, L., Berman, A., Mills, E., \& Perlman, J. (2003). The Costs and Financial Benefits of Green Buildings. A Report to California's Sustainable Building Task Force.

Kirsten, K. (2007). Go Green for Greater Employee Wellbeing and Performance Says.

Leather, P., Pyrgas, M., Beale, D., \& Lawrence, C. (1998). Windows in the Workplace: Sunlight, View, and Occupational Stress. Environment \& Behavior, 30(3). https://doi.org/10.1177/001391659803000601

Lercher, P., Hortnagl, J., \& Kofler, W. W. (1993). Work Noise Annoyance and Blood Pressure: Combined Effects with Stressful Working Conditions. International Archives of Occupational and Environmental Health, 6. https://doi.org/10.1007/BF00586054

Loftness, V., Hartkopf, V., Gurtekin, B., Hansen, D., \& Hitchcock, R. (2003). Linking Energy to Health and Productivity in the Built Environment. Center for Building Performance and Diagnostics, 12.

Milton, D. K., Glencross, M., \& Walters, M. D. (2000). Risk of Sick Leave Associated with Outdoor Air Supply Rate, Humidification, and Occupant Complaints. Indoor Air, 10, 10. https://doi.org/10.1034/j.16000668.2000.010004212.x

Newsham, G., Brand, J., Donnelly, C., Veitch, J., Aries, M., \& Charles, K. (2009). Linking Indoor Environment Conditions to Job Satisfaction: A Field Study. Building Research \& Information, 37(2). https://doi. org/10.1080/09613210802710298

Onsman, H. (1999). The Secret of a Happy Office. Business Review Weekly, 21(22), 46.

Park, J. S., \& Yoon, C. H. (2011). The Effects Of Outdoor Air Supply Rate on Work Performance During 8-h Work Period. Indoor Air, 21(4). https://doi. org/10.1111/j.1600-0668.2010.00700.x PMid:21204987 PMCid:PMC3121221 
Qasim, S., Cheema, F.-E.-A., \& Syed, N. A. (2012). Exploring Factors Affecting Employees' Job Satisfaction at Work. Journal of Management and Social Sciences, 8(1).

Ritz, A. (2009). Public service Motivation and Organizational Performance in Swiss Federal Government. International Review of Administrative Sciences, 75(1). https://doi.org/10.1177/0020852308099506

Samaranayake, S. U., \& De Silva, S. (2010). Effect of Green Workplace Environment on Employee Performance. International Conference on Sustainable Built Environment (ICSBE-2010), 9.

Sentman, S. D. (2009). Healthy Buildings: Green building Standards, Benefits, and Incentives. Journal of Biolaw and Business, 12(1), 4.

Seppänen, O. F., William J, \& Lei, Q. (2006). Effect of Temperature on Task Performance in Office Environment. Berkeley Lab.

Sink, D. (1985). Productivity Management: Planning, Measurement and Evaluation, control and improvement.

Spector, P. E. (1997). Job Satisfaction: Application, Assessment, Causes and Consequences: Sage Publications, Inc.

Sullivan, J., Baird, G., \& Donn, M. (2013). Measuring Productivity in the Office Workplace Centre for building Performance Research. New Zealand: Victoria University of Wellington. PMid:23625836

Sundstrom, E., Town, J. P., Rice, R. W., Osborn, D. P., \& Brill, M. (1994). Office Noise, Satisfaction, and
Performance. Evironment and Behavior, 26(2). https://doi.org/10.1177/001391659402600204

Sypniewska, B. A. (2013). Evaluation of Factors Influencing Job Satisfaction. Vizja Press \& IT, 8(1). https://doi. org/10.5709/ce.1897-9254.131

Togia, A., Koustelios, A., \& Tsigilis, N. (2004). Job Satisfaction among Greek Academic Librarians. Library \& Information Science Research, 26, 11. https://doi. org/10.1016/j.lisr.2004.01.004

Tutuncu, O., \& Kozak, M. (2007). An Investigation of Factors Affecting Job Satisfaction. International Journal of Hospitality \& Tourism Administration, 8(1), 1-19. https://doi.org/10.1300/J149v08n01_01

U.S. Green Building Council. (2015). LEED V4 for Building Design and Construction.

Waqas, A., Bashir, U., Sattar, M. F., Abdullah, H. M., Hussain, I., Anjum, W., . . . Arshad, R. (2014). Factors Influencing Job Satisfaction and its Impact on Job Loyalty. International Journal of Learning and Development, 4(2), 20. https://doi.org/10.5296/ijld.v4i2.6095

Wyon, D. (2004). The Effects of Indoor Air Quality on Performance and Productivity. Indoor Air, 14(7). https://doi.org/10.1111/j.1600-0668.2004.00278.x PMid:15330777

บุญเกียรติ วิสิทธิกาศ. (2552). ความต้องการอาคารเขียวของผู้เช่าสำนักงานระดับเอ. วิทยานิพนธ์สถาปัตยกรรมศาสตร์ จุฬาลงกรณ์มหาวิทยาลัย. 